\title{
Mathematical problem-solving abilities and reflective thinking abilities: The impact of the influence of eliciting activities models
}

\author{
Suci Hartati ${ }^{1}$, Ratu Ayu Bilqis ${ }^{2}$, Achi Rinaldi2 \\ ${ }^{1}$ Universitas Pancasakti Tegal, Indonesia \\ ${ }^{2}$ Universitas Islam Negeri Raden Intan Lampung, Indonesia \\ muhirfan@mercubuana-yogya.ac.id
}

\section{Article Information \\ Submitted June 16, 2020 \\ Revised June 20, 2020 \\ Accepted June 24, 2020}

\section{Keywords}

Model Eliciting Activities; Mathematical Problem Solving; Reflective Thinking.

\section{Abstract}

This study aims to determine the effect of the Model Eliciting Activities (MEAs) learning model to the mathematical problem-solving abilities and the mathematical reflective thinking skills. This research is a type of Quasi Experimental Design research. Data collection techniques in this study in the form of documentation and tests at the public school in Bandar Lampung with 30 students of experiment classes and 30 students of control classes. Data analysis techniques used are the normality and homogeneity test. Testing hypothesis in this study using the Multivariate Analysis of Variance (MANOVA) test. Based on the result of this study, the calculation of the MANOVA test, it was concluded that there was an influence of the Model Eliciting Activities (MEAs) to the mathematical problem-solving abilities and the mathematical reflective thinking skills. The application of the Model Eliciting Activities to the mathematical problem-solving abilities and the mathematical reflective thinking skills has a relatively high level of effectiveness.

\section{INTRODUCTION}

The mathematical reflective thinking ability makes it easy for students to face and solve problems in mathematics (Fuady, 2017). Reflection in mathematics can hone students' ability to solve problems systematically and conceptually (Tisngati, 2015). Mathematical reflective thinking ability is important to develop in students because the results of learning activities and problem solving will be comparable to the reflective thinking ability possessed by students. In addition to mathematical reflective thinking, problem solving skills are also very necessary in the process of learning mathematics.

The ability of problem solving is a skill to make decisions and draw conclusions based on logical, rational, critical, intelligent, honest, efficient, and effective thinking (Ilyyana, 2018). Good mastery of problem solving skills enables students to solve everyday problems, learn about rational science, be skilled in applying mathematics and have confidence (Mufida et al., 2018).

It is fitting as an educator to make the latest innovations in the learning process so that students do not feel bored, bored and always motivated in learning mathematics (Supardi et al., 2018). The innovation can be in the form of a learning model that is an appropriate and effective learning model so that the learning process in the classroom can run smoothly and in accordance with what is expected.

The learning model serves to direct educators to design learning that is used as a reference to the implementation of learning aimed at achieving effective, efficient, high-interest learning 
towards learners' interests. Model Eliciting Activities (MEAs) is one of the learning models that can help to improve reflective thinking and students' mathematical problem solving abilities.

Model Eliciting Activities has 5 steps in the learning process, namely educators read problem sheets that are useful in building the context of students (Submitting Problems), students listen carefully to questions read based on the problem sheets that have been given (Responding to Problems), educators ensure that each group understand what is being asked (Understanding Problems), students and their groups try to solve these problems (Creating Mathematical Models), and finally students present their mathematical models after discussing and reviewing solutions (Presentation).

Several studies related to the Eliciting Activities Model that have been done previously by several researchers show that the Eliciting Activities Model is effective for improving students' critical thinking skills (Delfia, et al., 2020), think creatively ( Aziz, S. A., \& Irwan, I, 2020), mathematics learning achievement (Juniantari, 2019), ability of representation (Graphs, 2020), mathematical communication skills (Anggralia et al., 2019), and students' mathematical understanding abilities (Santia, et al., 2020), mathematical creative thinking (Winda et al., 2018), the learning process based on the MEAs approach applied to class X students in the first semester is valid, practical and effective (Irwan et al., 2018), able to prepare students to solve real-life problems by applying mathematical concepts (Pertamawati \& Retnowati, 2019), and MEAs learning using the MT approach achieves both quantitative and qualitative criteria for student self-efficacy (Setiani et al., 2018).

Other studies related to mathematical problem solving abilities have also been carried out by Putri Safrina, et al. The results of the study concluded that the achievement and improvement of students 'mathematical problem solving abilities by using CORE learning models with an open-ended approach is better than achieving and increasing students' mathematical problem solving abilities using expository learning (Wahyuningtyas et al., 2020), research by Leonardus Hendra, et al. with the results of the research the problem solving ability and the ability of the representation of students who learn with multi-representation learning strategies with a conceptual problem solving approach is higher than students who study with conventional learning (Aha, 2019), research from Apri Kurniawan and Gida Kadarisma, the results of the study concluded that there was a moderate positive correlation between mathematical disposition of problem solving ability with a correlation of 0.556 and a coefficient of determination of 0.309 at a significant level of 0.05 . This shows that the mathematical disposition has a positive contribution to the ability of problem solving (Mayratih et al., 2019), research from Wayan Partayasa, et al. the results of the study showed that the students' mathematical problem solving skills following the CPS model assisted with video learning were better than conventional learning. Furthermore, for students who have a higher or lower interest in learning, the application of CPS-assisted video learning models is better than conventional learning (Partayasa, 2020), research from Fitrah Sari W, et al with the results of the study concluded that the syntax or stages of inquiry learning provide support to the learning process in improving students' mathematical problem solving abilities (Harahap \& Harahap, 2020), research from Dwi Rahmah D and Hasanuddin with the conclusion that there are differences in the mathematical problem solving ability of students who learn to use the Contexctual Teaching and Learning (CTL) learning model with students who learn to use conventional learning (Dayani, 2020), research from Winda Fitri Yani et al. found differences in mathematical 
problem solving between students who took the Osborn model and students who took conventional learning (Yani et al., 2020), Furthermore, research from Jenneri Anna Yarti and Hasanuddin stated that there are differences in the mathematical problem solving ability of students who learn to use the learning model of BBL (Brain Based Learning) with students who learn to use conventional learning (Sunaryo \& Nuraida, 2017), Research from Tahir and Marniati found that the SCAMPER method is better at developing students' problem solving skills with an average increase of 0.52 compared to conventional methods with an average increase of 0.45 (Fuadiah, 2019), and the last study from Sefna Rismen, et al. with the results of the study obtained the problem-solving ability of students who have more dominant impulsive cognitive styles are at low criteria (Rismen et al., 2020).

Similar to the ability to solve mathematical problems, research on reflective thinking ability has also been carried out by several previous researchers namely research from Meni Elpita and Irwandi where the results of the research are based on the results of research that have been done. It can be concluded that there are differences in reflective thinking ability between PBL and conventional learning in Biology learning excretion material at SMA Negeri 2 Kepahiang (Elpita, 2019), research from Laila Sari M, et al. there is a significant difference between the experimental class and the control class on reflective thinking skills and mathematical communication (Maqfirlana et al., 2019), research from Ratna Lestari, et al. states that the guided inquiry learning model influences students 'mathematical reflective thinking abilities, but does not affect students' self confidence (K. Kurniawati et al., 2019), research from Shely Selina R, et al with the conclusion that there is a significant interaction effect between learning models (pair check and direct) and the level of mathematical thinking habits on students' reflective thinking skills (Ramadhani et al., 2019), research from Yenni and Rika Sukmawati based on analysis of test results shows that students with high learning interest are able to master two indicators of reflective thinking ability well, and one other indicator that is not perfect. Students with moderate interest are only able to master one indicator of reflective thinking ability well, and two other indicators are not perfect. On the subject of this study, no students with low learning interest were found (Yenni, Y., \& Sukmawati, R, 2019), research from Nadlifah Alqonita can be concluded that there are differences in reflective thinking skills between experimental class students who use Thinking Aloud Pair Problem Solving learning methods assisted by LKPD media and control class students who use conventional learning methods (Alqonita, 2019), research from Monica Dewi W, et al shows that subjects who have a visual learning style are able to meet all the indicators in the reflective thinking phase, namely the reacting phase, the comparison phase, and the contemplating phase. Subjects who have an auditory learning style are only able to meet the indicators in the reflective thinking phase, namely the reacting phase, and the comparison phase. Subjects who have kinesthetic learning styles are only able to meet the indicators in the reflective thinking phase, namely the reacting phase (Wulansari et al., 2019), research from Reyna Suhartina et al. the results obtained are the level of mathematical reflective thinking ability of junior high school students in Cimahi City based on written tests and the results of interviews with Cimahi students are still relatively low and there is no influence between the independence of student learning (Self Regulated) with the ability of mathematical relective thinking (Suhartina et al., 2019), Furthermore, research from Anissa Listiana M, the results of this study concluded that the increase in mathematical reflective thinking ability (KBRM) of students whose learning using the ITBSM model is better 
than students whose learning is expository (Maharani, et al., 2019), and the last research from Lia Kurniawati, et al. results showed that the mathematical reflective thinking ability of students who were taught using the Lesson Shift-Problem learning approach as a whole was higher than students who were taught using conventional learning approaches. Thus it can be concluded that the Lesson Shift-Problem learning approach has a significant effect on students' mathematical reflective thinking abilities (L. F. M. R. M. Kurniawati, 2019).

Based on the results of the research above, researchers are interested in conducting research with the aim of seeing the effect of Model Eliciting Activities (MEAs) on the ability of mathematical problem solving and reflective thinking of students. The research objective is as an effort to improve students' mathematical problem solving abilities and reflective thinking skills using the Model Eliciting Activities. The Model of Eliciting Activities has been widely studied, but it is still rarely used by students in their mathematical problem solving abilities and reflective thinking.

\section{METHODS}

This type of research is Quasi Experimental Design which consists of two classes, namely the experimental class and the control class. The experimental class will use the Model Eliciting Activities (MEAs) in the learning process while the control class uses conventional learning.

Based on Figure 1, this study aims to determine the effect of applying Model Eliciting Activities (MEAs) to students' mathematical problem solving abilities and reflective thinking. Based on Figure 2, Electricity Activity Model (MEAs) has 5 steps, namely the delivery of problems, responding to problems, understanding problems, making mathematical models and presentations. Through each step in the MEAs it is expected to be able to improve the reflective thinking ability of mathematics and the problem of mathematical ability to solve. Responding to problems and making mathematical models are used to practice problem solving skills while understanding problems and presentations are used to practice mathematical reflective thinking skills. The design of this research is posttest design. Here is the research design:

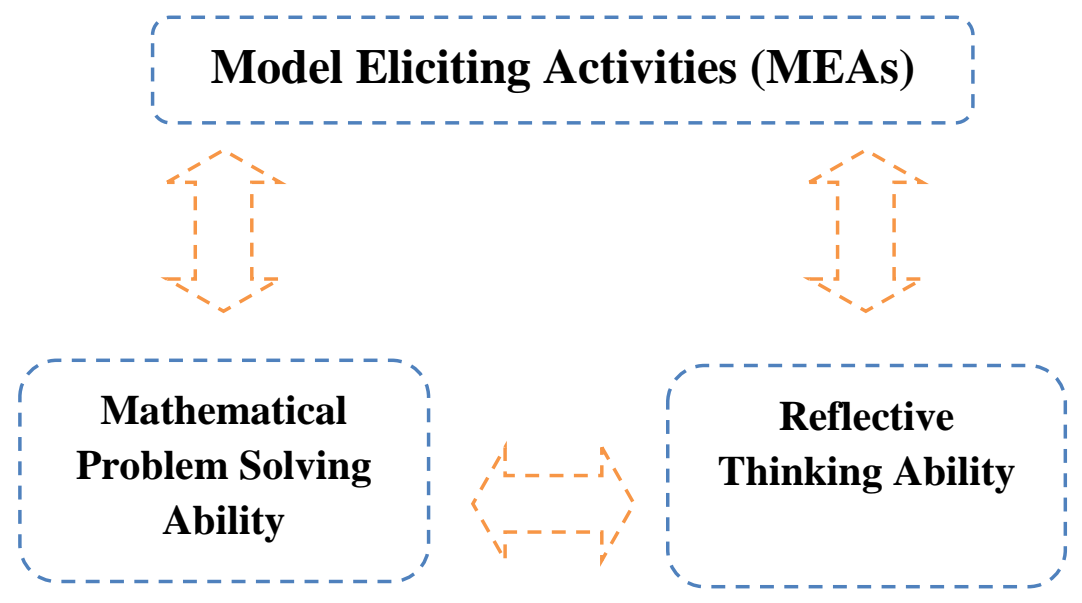

Figure 1. Research Design 


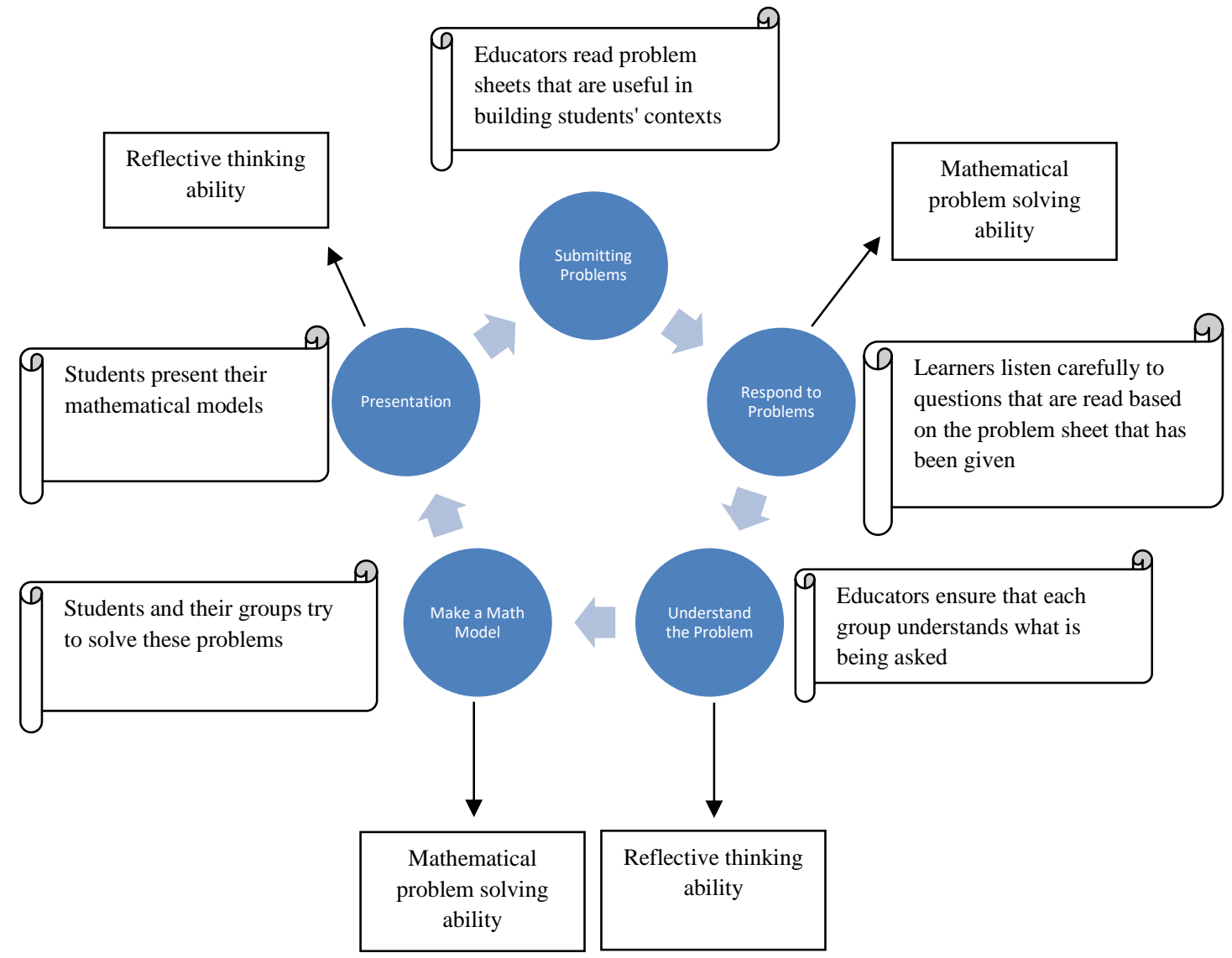

Figure 2. Steps to the Model Eliciting Activities

The ability of reflective thinking is mathematically influenced by students' self-confidence, because students who have the level of confidence to never give up in facing a given problem. In addition, the relationship between mathematical ability and the attitude of a person in dealing with problems is also influenced by learning factors that require students to be active in thinking and interacting, so as to increase mathematical abilities that are expected to be learning goals.

\section{Population and Sample}

The population used in this study were all students of class VIII at SMP Negeri 8 Bandar Lampung, totaling 270 students. The sample used consisted of two classes, namely the experimental class of 30 students and the control class of 30 students.

\section{Data collection technique}

Data collection techniques used in this study in the form of tests and documentation. The test that will be used in this research is in the form of an essay test. This test is conducted to find out the mathematical problem solving ability and the reflective thinking ability of students after the experiment learning model Eliciting Activities (MEAs) and in the form of documentation used in this study.

\section{Data analysis technique}

The prerequisite test used is the Lilliefors normality test, after the sample is known to come from a normal population then it is continued with the Bartlett homogeneity test, then if variance is obtained from a homogeneous population followed by a hypothesis test using the Multivariate Analysis of Variance (MANOVA) test using a computer program SPSS 22.0 


\section{RESULTS AND DISCUSSION}

After the data of problem solving ability and reflective thinking on tangent circle material collected both from the experimental class and from the control class obtained the highest value $\left(X_{\max }\right)$, lowest value $\left(X_{\min }\right)$ in the experimental class and the control class and look for the size of the central tendency includes averages $(\bar{X})$, median $(M e)$, modus $(M o)$ and the size of the group variance includes the range $(R)$ and standard deviation $(s)$ which can be summarized in the table below:

Table 1. Description of Observed Data Mathematical Problem Solving Ability

\begin{tabular}{ccccccccc}
\hline \multirow{2}{*}{ Group } & \multirow{2}{*}{$\boldsymbol{X}_{\boldsymbol{m a x}}$} & \multirow{2}{*}{$\boldsymbol{X}_{\boldsymbol{m i n}}$} & \multicolumn{3}{c}{ Central Tendency Size } & \multicolumn{2}{c}{ Size of Dispersion } \\
\cline { 8 - 10 } & & & $\bar{X}$ & $M_{e}$ & $M_{o}$ & $\mathrm{R}$ & $\mathrm{S}$ \\
Experiment & 89 & 44 & & 68.333 & 72 & 74 & 45 & 13.275 \\
Control & 48 & 7 & & 23.067 & 19 & 48 & 41 & 14.581 \\
\hline
\end{tabular}

Based on Table 1, it can be seen that the experimental class applying the Model Eliciting Activities (MEAs) has a post-test value for better mathematical problem solving ability than the control class. This can be seen from the highest value of 89 , the average value $(\bar{X})$ of 68,333 and the value that often appears $\left(M_{o}\right)$ amounted to 74 . The conclusion is that applying the Model Eliciting Activities (MEAs) can improve students' mathematical problem solving abilities.

Table 2. Description of Observation Data on Reflective Thinking Ability

\begin{tabular}{ccccccccc}
\hline \multirow{2}{*}{ Group } & \multirow{2}{*}{$\boldsymbol{X}_{\boldsymbol{m a x}}$} & \multirow{2}{*}{$\boldsymbol{X}_{\boldsymbol{m i n}}$} & & \multicolumn{3}{c}{ Central Tendency Size } & \multicolumn{2}{c}{ Size of Dispersion } \\
\cline { 1 - 4 } & & & $\bar{X}$ & $M_{e}$ & $M_{o}$ & $\mathrm{R}$ & $\mathrm{S}$ \\
Experiment & 100 & 50 & & 82.8 & 83 & 83 & 50 & 15.311 \\
Control & 92 & 42 & & 72.8 & 75 & 67 & 42 & 12.853 \\
\hline
\end{tabular}

Based on Table 2, it can be seen that the experimental class that applies the Model Eliciting Activities (MEAs) has a post-test value for better reflective thinking ability than the control class. This can be seen from the highest value of 100 , the average value $(\bar{X})$ of 82.8 and the value that often appears $\left(M_{o}\right)$ amounted to 83. The conclusion is that applying Model Eliciting Activities (MEAs) can improve students' reflective thinking skills. Following are the results of normality test calculations for mathematical problem solving abilities and reflective thinking of students that can be seen in the table below.

Table 3. Data Normality Test Mathematical Problem Solving Ability and Reflective Thinking of Students

\begin{tabular}{cccccc}
\hline No. & Class & Skills & $\boldsymbol{L}_{\text {count }}$ & $\boldsymbol{L}_{\text {table }}$ & Decision \\
\hline \multirow{2}{*}{1} & Experiment & Mathematical Problem & 0.1042 & 0.159 & $H_{0}$ Accepted \\
& & $\begin{array}{c}\text { Solving } \\
\text { Reflective thinking }\end{array}$ & 0.1306 & 0.159 & $H_{0}$ Accepted \\
& \multirow{2}{*}{ Control } & $\begin{array}{c}\text { Mathematical Problem } \\
\text { Solving }\end{array}$ & 0.1433 & 0.159 & $H_{0}$ Accepted \\
& & Reflective thinking & 0.1137 & 0.159 & $H_{0}$ Accepted \\
\hline
\end{tabular}

Based on table $3, L_{\text {count }}$ of each ability in each class has a lower value compared to $L_{\text {table }}$ with a significance level $5 \%$ so $H_{0}$ accepted which means the population is normally distributed in each group. Furthermore, the homogeneity test of students' mathematical problem solving abilities and reflective thinking can be seen in the table below: 
Table 4. Homogeneity Test

\begin{tabular}{|c|c|c|c|c|}
\hline No. & Sources & $X_{\text {count }}^{2}$ & $X^{2}$ table & Decision \\
\hline 1. & $\begin{array}{c}\text { Mathematical Problem } \\
\text { Solving }\end{array}$ & 0.25487247 & 5.591 & $H_{0}$ Accepted \\
\hline 2. & Reflective thinking & 0.88387373 & 5.591 & $H_{0}$ Accepted \\
\hline
\end{tabular}

Based on the above table, then with a significance level of $5 \%$ we can see that $X^{2}$ count for each ability has a value lower than $X^{2}$ table then $H_{0}$ can be accepted, it can be concluded that the sample comes from a homogeneous population. After we know that the data are normally distributed and come from a homogeneous population then the next is to test the hypothesis using the MANOVA test. The results of MANOVA calculations for hypotheses 1) and 2) can be seen in the table below:

Table 5. Hypothesis Test Results 1) and 2) Manova Test Data

\begin{tabular}{|c|c|c|c|c|c|c|}
\hline \multicolumn{7}{|c|}{ Tests of Between-Subjects Effects } \\
\hline Source & $\begin{array}{l}\text { Dependent } \\
\text { Variable }\end{array}$ & $\begin{array}{c}\text { Type III Sum of } \\
\text { Squares }\end{array}$ & Df & Mean Square & $\mathrm{F}$ & Sig. \\
\hline & PM & 30736.067 & 1 & 30736.067 & 158.454 & .000 \\
\hline$M E A s$ & $\mathrm{BR}$ & 1500.000 & 1 & 1500.000 & 7.507 & .008 \\
\hline
\end{tabular}

Based on table 5 above, it can be concluded that the value $p$-value in the ability to solve mathematical problems $(\mathrm{PM})=0.000$ with a value of $\alpha$ test criteria $=0.05$ which means the value $p$-value smaller than $\alpha$ test criteria, so $H_{0 A}$ rejected thus it can be concluded that there is an influence between the Model Eliciting Activities (MEAs) on the mathematical problem solving ability of students.

$p$-value in reflective thinking ability $(\mathrm{BR})=0.008$ with the value of $\alpha$ test criteria $=0.05$ which means the value $p$-value smaller than $\alpha$ test criteria, so $H_{0 A}$ rejected so it can be concluded that there is an influence between the Model Eliciting Activities (MEAs) on the reflective thinking ability of students.

After knowing the hypothesis test for each ability, then next calculate the hypothesis test for the 3rd hypothesis). The results of the MANOVA calculation for hypothesis 3) can be seen in the table below:

Table 6. Table of Hypothesis Test Results for Manova Test Data

\begin{tabular}{llccccc}
\hline \multicolumn{6}{c}{ MEAs } & \multicolumn{6}{c}{ Multivariate Tests $^{\mathrm{a}}$} \\
& Effect & Value & $\mathrm{F}$ & Hypothesis df & Error df & Sig. \\
& Pillai's Trace & .735 & $79.163^{\mathrm{b}}$ & 2.000 & 57.000 & .000 \\
& Wilks' Lambda & .265 & $79.163^{\mathrm{b}}$ & 2.000 & 57.000 & .000 \\
& Hotelling's Trace & 2.778 & $79.163^{\mathrm{b}}$ & 2.000 & 57.000 & .000 \\
& Roy's Largest & 2.778 & $79.163^{\mathrm{b}}$ & 2.000 & 57.000 & .000 \\
\hline
\end{tabular}

Based on the table above, it can be concluded that the value of Pillai's Trace, Wilks' Lambda, Hotelling's Trace, Roy's Largest Root $=0,000$ and $\alpha$ value of the test criteria $=0.05$ which means the value $p$-value smaller than $\alpha$ test criteria, so $H_{0 A B}$ rejected so it can be concluded that there is an influence between the Model Eliciting Activities (MEAs) on the ability of mathematical problem solving and students' reflective thinking skills. 
The results obtained by researchers have a relationship with the results of previous studies conducted by Sarah Nurshiami Sopandi, the results of his research showed that increasing the critical thinking skills of students who obtained model-learning activities (MEAs) increased (Delfia, et al., 2020). Furthermore, research conducted by S A Aziz and I Irawan which results of the research show that mathematics learning tools based on the MEAS approach can improve students' creative thinking abilities ( Aziz, S. A., \& Irwan, I, 2020), Research from Made Juniantari states that there is a positive influence on the eliciting activities model on students' mathematics learning achievement (Juniantari, 2019), Subsequent research from Zairisma, et al with the results of his research that the mathematical representation ability of students taught using MEA with STAD type is better than conventional learning (Graphs, 2020), research from Rema Anggralia, et al whose research results show that there is a significant effect of the MEAs approach to students' mathematical communication skills (Anggralia et al., 2019), research from Winda et al., shows that the Model Eliciting Activities (MEAs) can be one of the approaches used to improve students' mathematical creative thinking abilities (Winda et al., 2018), Other research conducted by Irwan et al. concluded that the learning process based on the MEAs approach applied to class X students in the first semester was valid, practical and effective (Irwan et al., 2018), Furthermore, research from Nina Santia et al. can be concluded that the application of contextual-based Eliciting Activities (MEAs) models can improve students' mathematical understanding abilities and contextual-based Eliciting Activities (MEAs) models are more effectively used compared to conventional learning (Santia, 2020), the research from Pertamawati and Retnowati, the research shows that the implementation of MEAs is able to prepare students to solve real-life problems in the future by applying mathematical concepts that have been learned in school (Pertamawati \& Retnowati, 2019), and finally research from Setiani et al. shows that MEAs learning using the MT approach achieves both quantitative and qualitative criteria for student self-efficacy (Setiani et al., 2018).

Learning activities Model Eliciting Activities (MEAs) begin by informing the learning objectives to be obtained, then informing the material to be learned, and explaining the process of implementing learning according to the steps. The next stage is dividing students into several small groups of 4-5 students per group. Next the educator distributes the problem sheets to each group and the educator asks each group to observe the problems contained in the discussion sheet. Educators provide the opportunity to ask questions about the problems contained in the discussion sheet, after that the educator asks students to read the problems in the discussion sheet again and make sure each group understands the problem that must be solved. Educators ask students to solve the problems contained in the discussion sheet together with their respective groups, at the same time educators guide and supervise students in finding concepts from the material being studied. After discussing the problem in groups, the educator then asks students to present the results of the problem solving that has been discussed with the group. The final stage is the educator confirms the results of presentations that have been delivered by students and directs students to conclude the results of the discussion of the learning that has been done. The following is an overview of activities in the learning process using the Model Eliciting Activities. 


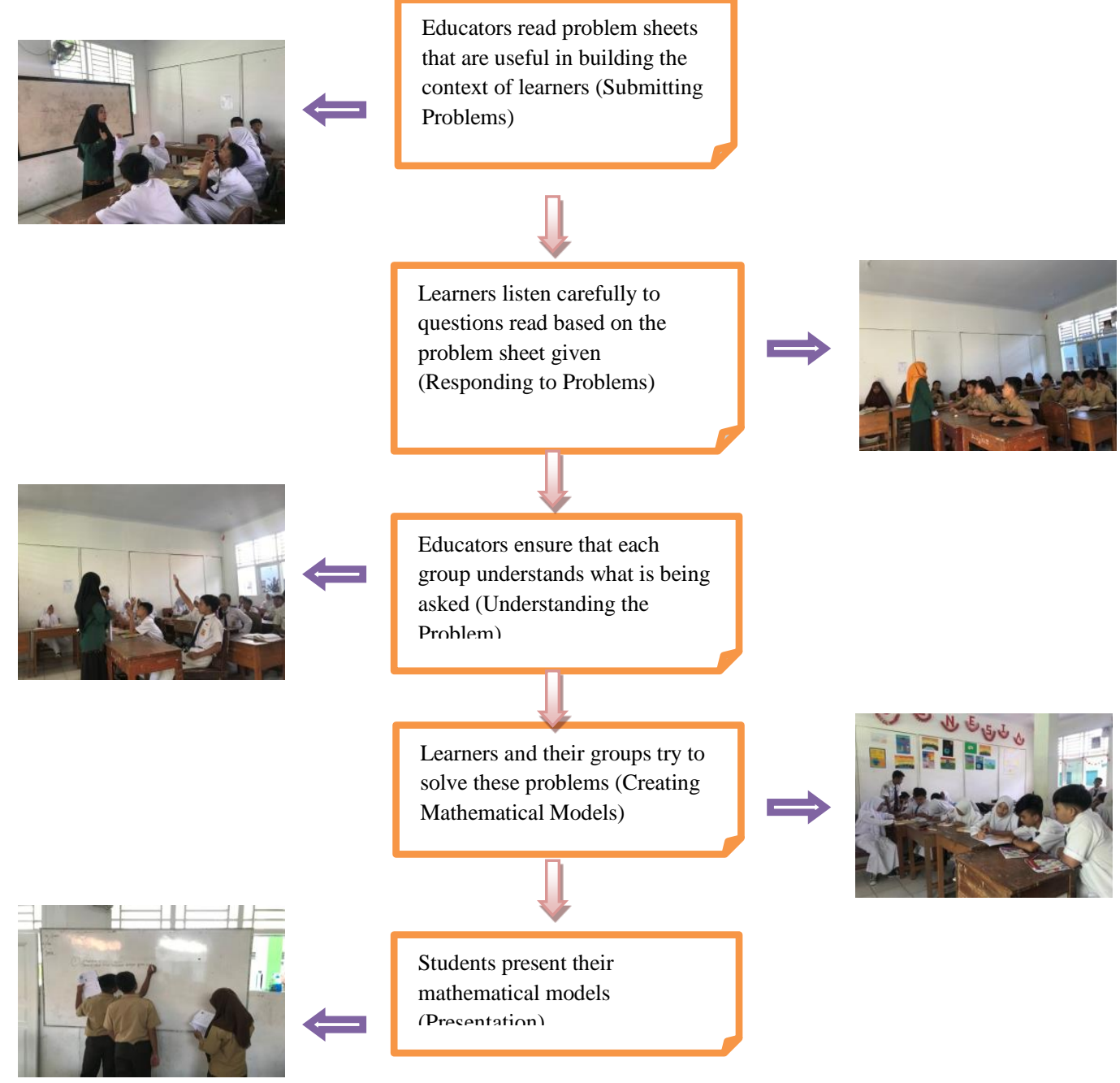

Figure 3. Learning activities using the Model Eliciting Activities

Based on the description of the steps Model Eliciting Activities (MEAs) it can be seen that the steps in MEAs are more effective in improving students' mathematical problem solving abilities and reflective thinking compared to conventional ones. The application of the SSCS learning model also makes students more focused in the process of group discussion, this is because the stages of group discussion in the learning model are very structured, starting from responding to problems, understanding problems, making mathematical models and finally presentation. If students can follow all the stages properly, students will be able to understand and solve mathematical problems properly.

\section{CONCLUSIONS}

Based on the results of the analysis and discussion in this study, it can be concluded that there is an influence of the Eliciting Actions Model (MEAs) on the ability to solve mathematical problems. There is an influence of Eliciting Actions Models (MEAs) on the ability to think reflective. There is an influence of Eliciting Actions Models (MEAs) on students' mathematical problem solving abilities and reflective thinking. The application of Election Model Actions 
(MEAs) has a high level of effectiveness for students' mathematical problem solving abilities and reflective thinking compared to conventional learning.

Researchers expect further research that wants to examine the ability of mathematical problem solving and reflective thinking can use other learning models that are more effective than the learning models that have been studied by researchers. It aims to see the effectiveness of other learning models for students' mathematical problem solving abilities and reflective thinking.

\section{AUTHOR CONTRIBUTIONS STATEMENT}

$\mathrm{SH}$ and $\mathrm{RAB}$ worked as the main drafter in this study. AR assists the implementation and design of research articles.

\section{REFERENCES}

Aha, L. H. (2019). Pengaruh strategi pembelajaran multirepresentasi dengan pendekatan conceptual problem solving (CPS) terhadap kemampuan pemecahan masalah dan kemampuan representasi siswa kelas X. Jurnal Pendidikan: Teori, Penelitian dan Pengembangan. 5(1), 44-51.

Alqonita, N. (2019). Kemampuan Berpikir reflektif siswa dengan metode pembelajaran thinking aloud pair problem solving (TAPPS) berbantuan media LKPD pada materi bangun ruang balok dan kubus. JPM : Jurnal Pendidikan Matematika, 4(2), 86.

Anggralia, R., Deswita, R., Erita, S., Habibi, M., \& Putra, A. (2019). Pengaruh pendekatan model-eliciting activities ( MEAs ) terhadap kemampuan komunikasi matematis siswa. Edumatica. 9. (2). 41-49.

Aziz, S. A., \& Irwan, I. (2020). Validity of mathematical learning material based on model eliciting activities (MEAS) approach to improve mathematical creative thinking skill of students. In Journal of Physics: Conference Series (Vol. 1554, p. 012066).

Dayani, R, D \& Hasanuddin. (2020). Pengaruh penerapan model pembelajaran contexctual teaching and learning (CTL) terhadap kemampuan pemecahan masalah matematis berdasarkan self confidence siswa SMP Negeri 1 Sungai Batang. Juring (Journal for Research in Mathematics Learning). 3(1), 91-100.

Elpita, M \& Irwandi, Irwandi. (2019). Kemampuan berpikir reflektif dengan mengunakan model PBL pada pembelajaran biologi di SMA Negeri 2 Kepahiang. SNSE VI. 2014, 15.

Delfia, S., Irwan, I., \& Yerizon, Y. (2020). Preliminary research of model eliciting activities learning based to improve junior high school students' mathematical critical thinking ability. In Journal of Physics: Conference Series (Vol. 1554, p. 012019).

Fuadiah, S. M. P. N. F. (2019). Kajian ilmu matematika dan pembelajarannya. Jurnal Silogisme. 2(2), 74-83.

Fuady, A. (2017). Berfikir reflektif dalam pembelajaran matematika. JIPMat, 1(2). 
Hartati, S., Bilqis, R. A., Rinaldi, A.

Graphs, D. Q. (2020). Odd harmonious labeling on edge. DESIMAL : JURNAL MATEMATIKA. $3(1), 65-72$.

Harahap, F. S. W., \& Harahap, A. S. M. (2020). Peningkatan kemampuan pemecahan masalah matematika siswa SMP menggunakan metode pembelajaran inkuiri. Seminar Nasional Teknologi Komputer \& Sains (SAINTEKS), 622-626.

Ilyyana, K. (2018). Analysis of problem solving ability in quadrilateral topic on model eliciting activities learning containing ethnomathematics. Unnes Journal of Mathematics Education Research, 7(2), 130-137.

Irwan, Asmar, A., \& Syarifuddin, H. (2018). The development of mathematical learning material based on model-eliciting activities (MEAs) approach to improve mathematical problem-solving skill of students of grade X of Senior High School Padang. Journal of Physics: Conference Series, 1040(1).

Juniantari, M. (2019). Pengaruh penerapan model eliciting activities terhadap prestasi belajar matematika siswa kelas VIII SMP. Journal of Education Technology, 3(1), 9.

Kurniawati, K., Noer, S. H., \& Gunowibowo, P. (2019). Pengaruh model pembelajaran inkuiri terbimbing terhadap kemampuan berpikir reflektif dan self efficacy. Jurnal Pendidikan Matematika, 7(1), 65-77.

Kurniawati, L. F. M. R. M. (2019). Pengaruh pendekatan pembelajaran shift-problem lesson terhadap kemampuan berpikir reflektif matematis siswa. Ajme, 1(1), 35-43.

Maqfirlana, L. S., Sunismi, \& Fathani, A. H. (2019). Kemampuan berpikir reflektif dan komunikasi matematis melalui model jucama berbasis neurosains berbantuan software animiz materi segiempat kelas VII. Jurnal Penelitian, Pendidikan, Dan Pembelajaran, 14(7), 57-68.

Mayratih, G. E., Leton, S. I., \& Uskono, I. V. (2019). Pengaruh disposisi matematis terhadap kemampuan pemecahan masalah matematis siswa. Asimtot: Jurnal Kependidikan Matematika, 1(1), 41-49.

Mufida, A., Suyitno, H., \& Marwoto, P. (2018). Analysis of mathematical problem solving skills using meta-cognitive strategy from the perspective of gender-based self-efficacy. Unnes Journal of Mathematics Education Research, 7(2), 138-144.

Maharani, A. L., Nindiasari, H., \& Fatah, A. (2019, November). Penerapan model inquiri terbimbing berbasis scaffolding metakognitif upaya meningkatkan disposisi berpikir reflektif matematis berdasarkan tahapan perkembangan kognitif siswa SMA. In Prosiding Seminar Nasional \& Call For Papers.

Partayasa, W. (2020). Pengaruh model pembelajaran creative problem solving (CPS) berbantuan video pembelajaran terhadap kemampuan pemecahan masalah ditinjau dari minat. JNPM (Jurnal Nasional Pendidikan Matematika), 4(1), 168.

Pertamawati, L., \& Retnowati, E. (2019). Model-eliciting activities: Engaging students to make sense of the world. Journal of Physics: Conference Series, 1200(1). 
Ramadhani, S. S., Hartin, S., Lestari, W. D., Wiralodra, U., Reflektif, K. B., Pembelajaran, M., \& Check, P. (2019). Pengaruh penggunaan model pembelajaran pair check terhadap kemampuan berpikir reflektif siswa ditinjau dari tingkat kebiasaan berpikir. Proximal: Jurnal Penelitian Matematika dan Pendidikan Matematika. 2, 1-10.

Rismen, S., Juwita, R., \& Devinda, U. (2020). Analisis kemampuan pemecahan masalah matematika siswa ditinjau dari gaya kognitif impulsif. Jurnal Gantang, 5(1), 61-68.

Santia, N., Effendi, A., \& Ruswana, A. M. (2020). Efektivitas penerapan model eliciting activities (MEAs) berbasis kontekstual untuk meningkatkan kemampuan pemahaman matematis siswa. J-KIP (Jurnal Keguruan dan Ilmu Pendidikan), 1(1), 8-15.

Setiani, C., Waluya, S. B., \& Wardono. (2018). Analysis of mathematical literacy ability based on self-efficacy in model eliciting activities using metaphorical thinking approach. Journal of Physics: Conference Series, 983(1).

Suhartina, R., Farhan, M. S., Kushendri, K., \& Nurjaman, A. (2019). Analisis kemampuan berpikir reflektif siswa smp di kota cimahi pada materi operasi aljabar ditinjau dari self regulated. Journal on Education, 1(3), 203-210.

Sunaryo, Y., \& Nuraida, I. (2017). Pengaruh penerapan model pembelajaran brain-based learning terhadap kemampuan pemecahan masalah matematik siswa. JP3M (Jurnal Penelitian Pendidikan dan Pengajaran Matematika), 3(2), 89-96.

Supardi, N., \& Rinaldi, A. (2018). Lembar kerja peserta didik berbasis kegiatan transaksi kewirausahaan materi sistem persamaan linier dua variabel. Desimal: Jurnal Matematika, $1(1), 49-55$.

Tisngati, U. (2015). Proses berpikir reflektif mahasiswa dalam pemecahan masalah pada materi himpunan ditinjau dari gaya kognitif berdasarkan langkah polya. Beta:Jurnal Tadris Matematika, 8(2), 142-152.

Wahyuningtyas, P. S., Setiani, Y., \& Khaerunnisa, E. (2020). Pengaruh model CORE dengan pendekatan open ended terhadap kemampuan pemecahan masalah matematis siswa SMP. Journal of Medives: Journal of Mathematics Education IKIP Veteran Semarang, 4(1), 81-96.

Winda, A., Sufyani, P., \& Elah, N. (2018). Analysis of creative mathematical thinking ability by using model eliciting activities (MEAs). Journal of Physics: Conference Series, 1013(1).

Wulansari, M. D., Purnomo, D., \& Utami, R. E. (2019). Analisis kemampuan berpikir reflektif siswa kelas VIII dalam memecahkan masalah matematika ditinjau dari gaya belajar visual dan auditorial. Imajiner: Jurnal Matematika Dan Pendidikan Matematika, 1(6), 393.

Yani, W. F., Muhandaz, R., \& Fitri, I. (2020). Pengaruh penerapan model pembelajaran osborn terhadap kemampuan pemecahan masalah matematis ditinjau dari pengetahuan awal matematis siswa SMA. JURING (Journal for Research in Mathematics Learning), 3(1), 053-064. 
Hartati, S., Bilqis, R. A., Rinaldi, A.

Yenni, Y., \& Sukmawati, R. (2019). Analisis kemampuan berpikir reflektif matematis berdasarkan minat belajar pada mata kuliah struktur ALJABAR. Teorema: Teori dan Riset Matematika, 4(2), 75-82. 